\title{
Candida saraburiensis sp. nov. and Candida prachuapensis sp. nov., xylose-utilizing yeast species isolated in Thailand
}

Correspondence Savitree Limtong fscistl@ku.ac.th

\author{
Sukanya Nitiyon, ${ }^{1}$ Chanita Boonmak, ${ }^{1,2}$ Somjit Am-In, ${ }^{3}$ \\ Sasitorn Jindamorakot, ${ }^{3}$ Hiroko Kawasaki, ${ }^{2}$ Wichien Yongmanitchai ${ }^{1}$ \\ and Savitree Limtong ${ }^{1}$
}

\author{
${ }^{1}$ Department of Microbiology, Faculty of Science, Kasetsart University, Bangkok, Thailand \\ ${ }^{2}$ Department of Biotechnology, NITE Biological Resource Center, National Institute of \\ Technological and Evaluation, Chiba, Japan \\ ${ }^{3}$ Bioresources Technology Unit, National Center for Genetic Engineering and Biotechnology \\ (BIOTEC), Pathumthani, Thailand
}

\begin{abstract}
Four strains of two novel xylose-utilizing yeast species were obtained from samples collected in Thailand from decaying corncobs (strains $\mathrm{KU}-\mathrm{Xs} 13^{\top}$ and $\mathrm{KU}-\mathrm{Xs18}$ ), a decaying grass (KU-Xs20) and estuarine water from a mangrove forest $\left(\mathrm{WB}^{\mathrm{T}} 5^{\mathrm{T}}\right)$. On the basis of morphological, biochemical, physiological and chemotaxonomic characteristics and sequence analysis of the D1/D2 domain of the large subunit rRNA gene, the four strains were found to represent two novel species of the genus Candida in the Candida albicans/Lodderomyces elongisporus clade. Three strains (KU-Xs13 ${ }^{\top}, \mathrm{KU}-\mathrm{Xs} 18$ and $\left.\mathrm{KU}-\mathrm{Xs} 20\right)$ were assigned as a single novel species, which was named Candida saraburiensis sp. nov. The type strain is $\mathrm{KU}-\mathrm{Xs} 13^{\top}\left(=\mathrm{CBS} 11696^{\top}=\mathrm{NBRC}\right.$ $\left.106721^{\top}=B C C 39601^{\top}\right)$. Strain $\mathrm{WB}^{\mathrm{T}} 5^{\top}$ represented another novel species of the genus Candida that was named Candida prachuapensis sp. nov. The type strain is WB15 ${ }^{\top}(=\mathrm{CBS}$ $11024^{\top}=$ NBRC $104881^{\top}=$ BCC $29904^{\top}$ ).
\end{abstract}

\section{INTRODUCTION}

Lignocellulose in plant biomass is currently of interest as a substrate for the production of many microbial products such as xylitol, acetic acid and ethanol (Carvalho et al., 2002; Doran-Peterson et al., 2008; Hahn-Hägerdal et al. 2006). D-Xylose is the second most abundant sugar in the lignocellulose of plant cell walls. It is a major sugar component of xylan, which is one of the principal polysaccharide constituents of lignocellulose. Many yeast species can assimilate xylose as a sole carbon source. In addition, many species have been tested for D-xylose fermentation (Barnett et al., 2000; Kurtzman \& Fell, 1998; Toivola et al., 1984). Only a few yeast species have been reported to ferment D-xylose to ethanol. These include Brettanomyces naardenensis, Candida lyxosophila, Candida intermedia, Candida shehatae, Candida tenuis, Pachysolen tannophilus, Pichia segobiensis, Scheffersomyces (Pichia) stipitis (Barnett et al., 2000; Kurtzman \& Fell, 1998),

Abbreviation: LSU, large subunit.

The GenBank/EMBL/DDBJ accession numbers for the sequence of the D1/D2 domain of the LSU rRNA gene of strains $\mathrm{KU}-\mathrm{Xs} 13^{\mathrm{T}}$ and $\mathrm{WB}^{\top}{ }^{\top}$ are $\mathrm{AB} 534915$ and $\mathrm{AB} 439258$, respectively.

A supplementary figure is available with the online version of this paper.
Candida jeffriesii, Spathaspora passalidarum (Nguyen et al., 2006) and Spathaspora arborariae (Cadete et al., 2009).

During investigations of xylose-utilizing yeasts and yeasts in mangrove forest ecosystems in Thailand, four xyloseutilizing yeast strains were found to represent two novel species of the genus Candida in the Candida albicans/ Lodderomyces elongisporus clade based on the analysis of the D1/D2 domain of the large subunit (LSU) rRNA gene sequence. In this paper, three $\mathrm{D}$-xylose-fermenting strains $\left(\mathrm{KU}-\mathrm{Xs} 13^{\mathrm{T}}, \mathrm{KU}-\mathrm{Xs} 18\right.$ and $\left.\mathrm{KU}-\mathrm{Xs} 20\right)$ are described as Candida saraburiensis sp. nov. and one D-xylose-assimilating strain $\left(\mathrm{WB}_{1} 5^{\mathrm{T}}\right)$, is described as Candida prachuapensis sp. nov.

\section{METHODS}

Yeast isolation and characterization. Xylose-utilizing yeasts were isolated from decaying agricultural residues and soil using an enrichment technique. Each sample $(1 \mathrm{~g})$ was added to $50 \mathrm{ml} \mathrm{D-}$ xylose-yeast nitrogen base (YNB) broth (2\% D-xylose, $0.67 \%$ Difco yeast nitrogen base; adjusted to $\mathrm{pH} 5.5$ with $1 \mathrm{M} \mathrm{HCl}$ ) supplemented with $0.025 \%$ sodium propionate and $200 \mathrm{mg}$ chloramphenicol $1^{-1}$ in a $250 \mathrm{ml}$ Erlenmeyer flask and incubated on a rotary shaker at $25^{\circ} \mathrm{C}$ for $48 \mathrm{~h}$. The enrichment culture was spread on D-xylose-YNB agar and incubated at $25{ }^{\circ} \mathrm{C}$. After incubation, yeast colonies were picked 
and purified by streaking on yeast extract malt extract (YM) agar $(0.3 \%$ yeast extract, $0.3 \%$ malt extract, $0.5 \%$ peptone, $1 \%$ glucose and $1.5 \%$ agar). Yeasts in estuarine water were isolated by a membrane filtration technique according to the method of Limtong et al. (2007a). Purified yeast strains were suspended in YM broth supplemented with $10 \%$ glycerol and maintained at $-80{ }^{\circ} \mathrm{C}$.

DNA sequencing and phylogenetic analysis. The sequences of the D1/D2 domain of the LSU rRNA gene were determined from PCR products amplified from genomic DNA that was extracted from yeast cells by using a slightly modified version of the method described by Lachance et al. (1999). The D1/D2 domain of the LSU rRNA gene was amplified by PCR with the forward primer NL-1 and the reverse primer NL-4 (O'Donnell, 1993). The PCR product was checked by agarose gel electrophoresis and purified by using the QIAquick purification kit (Qiagen). The purified PCR product was submitted to Macrogen Inc. (Korea) for sequencing with the external primers NL-1 and NL-4. The sequences were compared pairwise using a BLASTN search (Altschul et al., 1997) and were aligned with the sequences of related species retrieved from GenBank using the CLUSTAL_X version 1.81 multiple alignment program (Thompson et al., 1997). A phylogenetic tree was constructed from the evolutionary distance data with Kimura's two-parameter correction (Kimura, 1980) using the neighbour-joining method (Saitou \& Nei, 1987). Confidence levels of the clades were estimated from bootstrap analysis (1000 replicates) (Felsenstein, 1985).

Phenotypic characterization and xylose fermentation tests. The novel strains were characterized morphologically, biochemically and physiologically according to the standard methods described by Yarrow (1998). Assimilation of nitrogen compounds was examined on solid media with starved inocula following the method of Nakase \& Suzuki (1986). Growth at various temperatures was determined by cultivation in YM broth. Ubiquinones were extracted from cells cultivated in a $500 \mathrm{ml}$ Erlenmeyer flask containing $200 \mathrm{ml}$ yeast extract peptone glucose (YPG) broth ( $1 \%$ yeast extract, $2 \%$ peptone and $2 \%$ glucose) on a rotary shaker at $28{ }^{\circ} \mathrm{C}$ for $72 \mathrm{~h}$ and purified according to the methods described by Yamada \& Kondo (1973) and Kuraishi et al. (1985). The isoprenologues were identified by HPLC as described previously (Limtong et al., 2007b).

The fermentation of D-xylose was tested by cultivation in $50 \mathrm{ml} 4 \%$ D-xylose yeast extract peptone (YP) broth (4\% D-xylose, $2 \%$ peptone and $1 \%$ yeast extract) in a $250 \mathrm{ml}$ Erlenmeyer flask on a rotary shaker at 150 r.p.m. and $30^{\circ} \mathrm{C}$. Ethanol production and growth were measured at every $24 \mathrm{~h}$ for $120 \mathrm{~h}$. Ethanol was analysed by GC (GC9A; Shimadsu) with n-propanol as the internal standard and the cell concentration was determined at $\mathrm{OD}_{660}$. Scheffersomyces stipitis $\mathrm{CBS}$ $5773^{\mathrm{T}}$ was used as a positive control and Saccharomyces cerevisiae M30 was used as a negative control.

\section{RESULTS AND DISCUSSION}

\section{Species delineation, classification and ecology}

A total of 133 xylose-utilizing yeast strains were isolated from 84 samples of decaying agricultural residues and soils collected in various areas of Thailand. Seventy-eight strains were assigned to 18 recognized species in nine genera of the phylum Ascomycota (Barnettozyma californica, Candida blankii, Candida coipomoensis, Candida maltosa, Candida membranifaciens, Candida pseudointermedia, Candida pyralidae, Candida solani, Candida tropicalis, Debaryomyces hansenii var. fabryi, D. nepalensis, Geotrichum silvicola,
Lindnera rhodanensis, Pichia caribbica, Pichia kudriavzevii, Saturnispora saitoi, Sporopachydermia lactativora and Zygoascus hellenicus). Forty-two strains were assigned to nine recognized species in two genera of the phylum Basidiomycota (Cryptococcus cf. podzolicus, Cryptococcus heveanensis, Cryptococcus humicola, Cryptococcus laurentii, Cryptococcus terrestris, Trichosporon asahii, T. moniliiforme, T. mycotoxinivorans and T. terricola). Four strains were similar to three undescribed species and nine strains were found to represent seven novel species.

All 133 strains were tested for D-xylose fermentation using shake-flask cultivation. The results revealed that only eight strains could ferment D-xylose to ethanol. These were two strains of Zygoascus hellenicus (SN1-1 and SN1-4), three strains of Candida blankii (A6-1, A8-1 and A8-2) and three strains of a novel species (KU-Xs13 ${ }^{\mathrm{T}}, \mathrm{KU}-\mathrm{Xs} 18$ and $\mathrm{KU}-$ Xs20). Among the xylose-fermenting strains of the novel species, two strains $\left(\mathrm{KU}-\mathrm{Xs} 13^{\mathrm{T}}\right.$ and $\left.\mathrm{KU}-\mathrm{Xs} 18\right)$ were isolated from decaying corncobs and one strain (KUXs20) was obtained from decaying grass collected in Saraburi province, Thailand. The sequences of the D1/D2 domain of the LSU rRNA gene of strains KU-Xs13 ${ }^{\mathrm{T}}$ and $\mathrm{KU}$-Xs20 were identical and differed from the sequence of strain KU-Xs18 by only one gap out of $571 \mathrm{nt}$. With respect to their closest species in term of pairwise sequence similarity, the three new strains differed by $2.3 \%$ nucleotide substitutions (13 nt substitutions and one to two gaps out of $571 \mathrm{nt}$ ) from the type strain of Candida viswanathii and by $1.9 \%$ nucleotide substitutions (11 nt substitutions and one to two gaps out of $571 \mathrm{nt}$ ) from the type strain of Candida lodderae. Candida viswanathii and Candida lodderae were reported to be synonymous since they differ from each other by only two nucleotides in the D1/D2 domain of their LSU rRNA gene sequences (Kurtzman \& Robnett, 1997) and belong to the Candida albicans/Lodderomyces elongisporus clade. According to Kurtzman \& Robnett (1998), yeast strains showing nucleotide substitutions of greater than $1 \%$ in the D1/D2 domain of the LSU rRNA gene are usually representative of different species. The phylogenetic tree based on the sequences of the D1/D2 domain of the LSU rRNA gene further demonstrated that the three new strains (KU$\mathrm{Xs13}{ }^{\mathrm{T}}, \mathrm{KU}-\mathrm{Xs} 18$ and $\mathrm{KU}-\mathrm{Xs} 20$ ) formed a clade that was distinct from Candida viswanathii, Candida lodderae and other related species in the Candida albicans/Lodderomyces elongisporus clade (Fig. 1).

Strain $\mathrm{WB} 15^{\mathrm{T}}$ was isolated from estuarine water collected from a mangrove forest in Prachuap Khiri Khan province, Thailand, during another investigation of yeasts in mangrove forest ecosystems. Strain $\mathrm{WB}^{\mathrm{T}}{ }^{\mathrm{T}}$ showed the ability to assimilate but not ferment D-xylose, and represented another novel species. The closest species in terms of pairwise sequence similarity of the $\mathrm{D} 1 / \mathrm{D} 2$ domain of the LSU rRNA gene were Candida viswanathii and its synonymous species, Candida lodderae, but with $2.3 \%$ nucleotide substitutions (13 nt substitutions out of $570 \mathrm{nt}$ ) and $1.9 \%$ nucleotide substitutions (11 nt substitutions out 


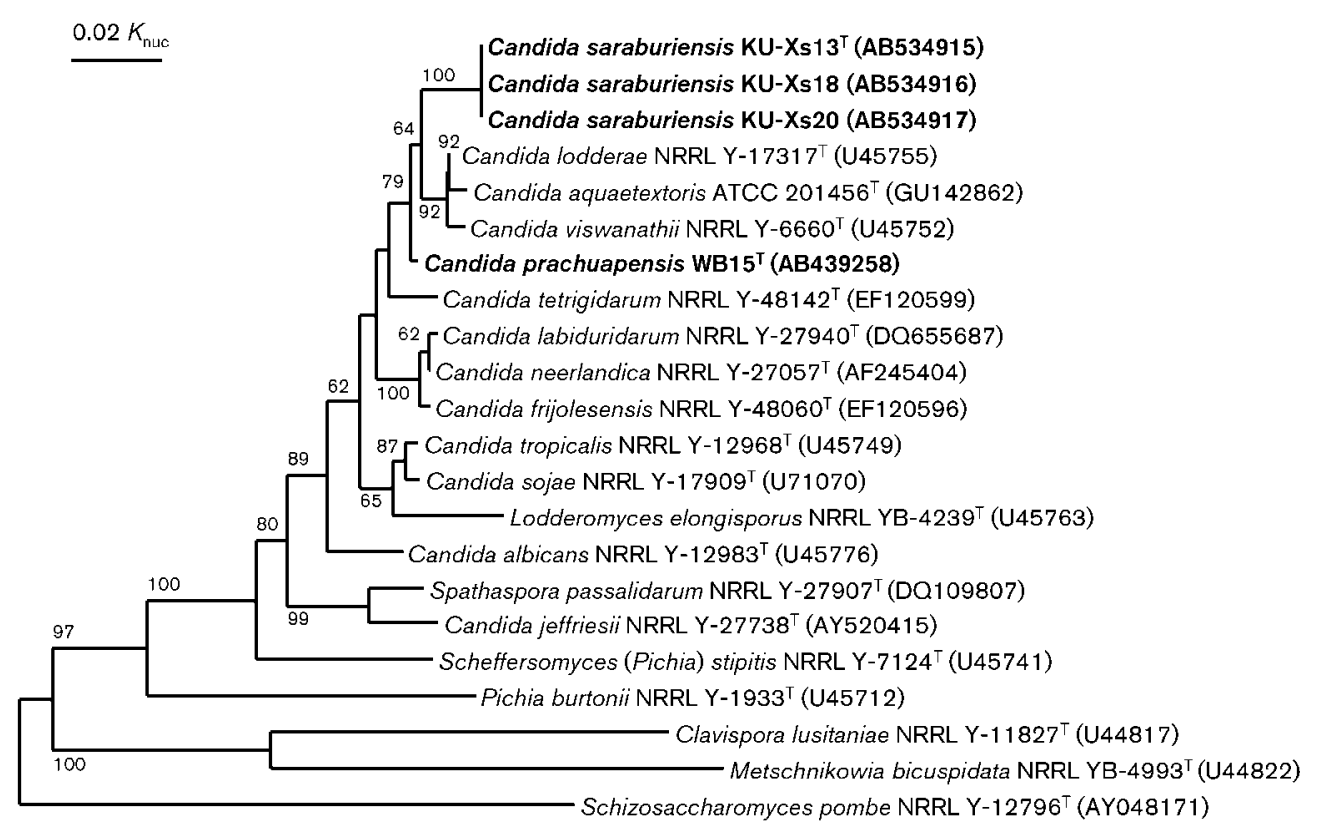

Fig. 1. Phylogenetic tree based on the sequences of the D1/D2 domain of the LSU rRNA gene showing the positions of Candida saraburiensis sp. nov. (KU-Xs13 ${ }^{\top}, \mathrm{KU}-\mathrm{Xs} 18$ and $\left.\mathrm{KU}-\mathrm{Xs} 20\right)$ and Candida prachuapensis sp. nov. (WB15 ${ }^{\top}$ ) with respect to closely related species. The phylogenetic tree was constructed from evolutionary distance data with Kimura's twoparameter correction (Kimura, 1980), using the neighbour-joining method. Numbers indicate the percentages of bootstrap sampling, derived from 1000 samples. Bar, $0.02 K_{\text {nuc. }}$.

of $570 \mathrm{nt})$, respectively. The sequence of strain $\mathrm{WB} 15^{\mathrm{T}}$ differed from those of strains $\mathrm{KU}-\mathrm{Xs} 13^{\mathrm{T}}$, KU-Xs18 and KU-Xs20 by $2.1 \%$ nucleotide substitutions (12 nt substitutions and one to two gaps out of $571 \mathrm{nt}$ ). In the phylogenetic tree (Fig. 1), strain $\mathrm{WB} 15^{\mathrm{T}}$ was placed in the Candida albicans/Lodderomyces elongisporus clade at a separate branch from Candida viswanathii, Candida lodderae and strains $\mathrm{KU}-\mathrm{Xs} 13^{\mathrm{T}}$, KU-Xs18 and KU-Xs20.

Cells of the novel strains proliferated by multilateral budding and were negative for Diazonium blue B and urease reactions. Starch-like compounds were not produced in common with the other members of Candida albicans/Lodderomyces elongisporus clade. Ascospores were not produced from individual strains or strains paired on $5 \%$ malt extract agar, Fowell's acetate agar, Gorodkowa agar or YM agar after 5 weeks at $25{ }^{\circ} \mathrm{C}$. These characteristics matched well with those of other members the genus Candida. Therefore, it was concluded that the four new strains represented two novel species. Strains KU-Xs $13^{\mathrm{T}}$, $\mathrm{KU}-\mathrm{X} 18$ and $\mathrm{KU}-\mathrm{Xs} 20$ were assigned to Candida saraburiensis sp. nov. with strain $\mathrm{KU}-\mathrm{Xs} 13^{\mathrm{T}}$ as the type strain. Strain $\mathrm{WB}^{\mathrm{T}} 5^{\mathrm{T}}$ was proposed as the type strain of Candida prachuapensis sp. nov.

Candida saraburiensis sp. nov. and Candida prachuapensis sp. nov. could be distinguished from each other and from Candida viswanathii and Candida lodderae, their closest recognized species, by many characteristics (as shown in Table 1).
The Candida albicans/Lodderomyces elongisporus clade consists of more than 20 species and includes some medically important species such as Candida albicans, Candida parapsilosis, Candida tropicalis and Candida viswanathii. The members of this clade have been isolated not only from humans, but also from soil, water, plants, insects and from industrial processes (Ji et al., 2009; Kurtzman et al., 2001; Meyer et al., 1998; Nguyen et al., 2007; Rao et al., 2007; Suh et al., 2008; Vallini et al., 1997). The two novel species of the genus Candida described in this study were obtained from different habitats. Strains of Candida saraburiensis sp. nov. were isolated from decaying corncobs and a decaying grass, while C. prachuapensis sp. nov. was isolated from estuarine water from a mangrove forest. The two novel species were closely related to Candida viswanathii, but it is not known whether they are pathogenic.

\section{Xylose fermentation}

Ethanol fermentation from xylose was determined for the four strains of the two novel species by shaking-flask cultivation using $4 \%$ D-xylose-YP broth. The results revealed that all three strains of Candida saraburiensis sp. nov. produced ethanol at 3.1-3.6 $\mathrm{g} \mathrm{l}^{-1}$ at $72 \mathrm{~h}$, but all ethanol was either consumed or evaporated after $96 \mathrm{~h}$ (see Supplementary Fig. S1 in IJSEM Online). Candida prachuapensis sp. nov. $\mathrm{WB}^{\mathrm{T}} 5^{\mathrm{T}}$ did not produce ethanol from xylose and displayed similar properties to the non-D- 
Table 1. Differential phenotypic characteristics of Candida saraburiensis sp. nov. and Candida prachuapensis sp. nov., Candida viswanathii and Candida lodderae

Taxa: 1, C. saraburiensis; 2, C. prachuapensis; 3, C. viswanathii and C. lodderae. +, Positive; w, weak; V, variable; -, negative; ND, not determined. Data for C. viswanathii and C. lodderae were taken from Meyer et al. (1998) and Barnett et al. (2000).

\begin{tabular}{|c|c|c|c|}
\hline Characteristic & 1 & 2 & 3 \\
\hline \multicolumn{4}{|l|}{ Fermentation of: } \\
\hline D-Galactose & W & - & $\mathrm{V}$ \\
\hline Maltose & $\mathrm{W}$ & + & + \\
\hline Sucrose & + & + & $\mathrm{V}$ \\
\hline Trehalose & + & - & $\mathrm{V}$ \\
\hline \multicolumn{4}{|l|}{ Assimilation of: } \\
\hline D-Galactose & + & - & + \\
\hline L-Sorbose & + & + & $\mathrm{V}$ \\
\hline D-Ribose & - & - & $\mathrm{V}$ \\
\hline L-Arabinose & - & - & $\mathrm{V}$ \\
\hline Cellobiose & $\mathrm{W}$ & + & + \\
\hline Salicin & $\mathrm{W}$ & + & $\mathrm{V}$ \\
\hline Melibiose & - & $\mathrm{w}$ & - \\
\hline Raffinose & - & + & - \\
\hline Inulin & - & + & - \\
\hline Soluble starch & - & + & + \\
\hline 5-Ketogluconic acid & - & + & + \\
\hline DL-Lactic acid & + & + & - \\
\hline \multicolumn{4}{|l|}{ Growth at/with } \\
\hline Vitamin-free medium & + & + & - \\
\hline $0.01 \%$ Cycloheximide & - & - & + \\
\hline $0.1 \%$ Cycloheximide & - & - & + \\
\hline $60 \%$ Glucose & + & + & - \\
\hline $16 \% \mathrm{NaCl} / 5 \%$ glucose & + & ND & - \\
\hline Acid formation from glucose & + & ND & - \\
\hline $40{ }^{\circ} \mathrm{C}$ & + & + & $\mathrm{v}$ \\
\hline $42{ }^{\circ} \mathrm{C}$ & - & $\mathrm{w}$ & - \\
\hline
\end{tabular}

xylose fermenting reference yeast, Saccharomyces cerevisiae M30. In the same experiment Scheffersomyces stipitis CBS $5773^{\mathrm{T}}$, the $\mathrm{D}$-xylose-fermenting control yeast strain, produced the highest ethanol concentration at $8.4 \mathrm{~g} \mathrm{l}^{-1}$ after $72 \mathrm{~h}$, although ethanol was also reduced to $6.3 \mathrm{~g} \mathrm{l}^{-1}$ and $2.2 \mathrm{~g} \mathrm{l}^{-1}$ after $96 \mathrm{~h}$ and $120 \mathrm{~h}$, respectively. In contrast, when D-xylose fermentation was tested by the standard methods described by Yarrow (1998), i.e. the Durham tube fermentation test, all four strains gave a negative result.

\section{Latin diagnosis of Candida saraburiensis Nitiyon, Boonmak, Am-In, Jindamorakot, Kawasaki, Yongmanitchai et Limtong sp. nov.}

In agaro YM post dies 3 ad $25{ }^{\circ} \mathrm{C}$ cellulae ovoidae aut cylindricae, $(2-6 \times 4-10 \mu \mathrm{m})$, singulae, binae, aut pseudohyphae fiunt, per germinationem multipolarem reproducentes. Cultura butyrosa, cremea, glabra, seminitidae, centrum colonia altum, margine glabra. In agaro YM post dies 5 ad $25{ }^{\circ} \mathrm{C}$ pseudohyphae formantur, hyphae non formantur. Ascosporae non formantantur. D-Glucosum, D-galactosum (infirme), maltosum (infirme), sucrosum et $\alpha, \alpha$-trehalosum fermentantur at non melibiosum, lactosum nec raffinosum. D-Glucosum, Dgalactosum, L-sorbosum, N-acetyl-D-glucosaminum, D-xylosum, sucrosum, maltosum, $\alpha, \alpha$-trehalosum, methyl $\alpha$-D-glucosidium, cellobiosum (infirme), salicinum (infirme), melezitosum, glycerolum, ribitolum, D-glucitolum, D-mannitolum, D-glucono-1,5lactonum, acidum 2-ketogluconicum, acidum D-gluconicum, acidum DL-lacticum, acidum succinicum, acidum citricum, ethanolum, ethylaminum, L-lysinum et cadaverinum assimilantur. D-Ribosum, L-arabinosum, D-arabinosum, L-rhamnosum, melibiosum, lactosum, raffinosum, inulinum, amylum solubile, erythritolum, galactitolum, inositolum, acidum 5ketogluconicum, acidum D-glucuronicum, acidum D-galacturonicum, methanolum, kalium nitricum nec natrum nitrosum non assimilantur. Vitamina externa crescentiae non necessaria sunt. Crescit postest in temperatura $40{ }^{\circ} \mathrm{C}$ at non in $42{ }^{\circ} \mathrm{C}$. Non crescit in $0.01 \%$ cycloheximido nec $0.1 \%$ cycloheximido. Crescit in $50 \%$ glucosum, $60 \%$ glucosum, $10 \%$ natrii chloridum $/ 5 \%$ glucosum et $16 \%$ natrii chloridum $/ 5 \%$ glucosum. Amylum non formatur. Ureum non hydrolysatur. Diazonium caeruluem B non respondens. Ubiquinonum majus: Q-9.

Typus stirpis, KU-Xs13 $3^{\mathrm{T}}\left(=\mathrm{CBS} 11696^{\mathrm{T}}=\mathrm{NBRC} 106721^{\mathrm{T}}\right.$ $=\mathrm{BCC} 39601^{\mathrm{T}}$ ) isolatus digesta granum core, Saraburi provicia, Thailandica, conservatur in collectionibus culturarum quas Centraalbureau voor Schimmelcultures (Utrecht, The Netherlands), NITE Biological Resource Center (Chiba, Japan) et BIOTEC Culture Collection, National Centre for Genetic Engineering and Biotechnology, Thailand (Pathumthani, Thailand) deposita est.

\section{Description of Candida saraburiensis Nitiyon, Boonmak, Am-In, Jindamorakot, Kawasaki, Yongmanitchai \& Limtong sp. nov.}

Candida saraburiensis (sa.ra.bu.ri.en'sis. N.L. fem. adj. saraburiensis of or belonging to Saraburi, Thailand).

After growth on YM agar for 3 days at $25{ }^{\circ} \mathrm{C}$, cells are ovoid to cylindrical $(2-6 \times 4-10 \mu \mathrm{m})$ and occur singly, in pairs or in short chains (Fig. 2). Budding is multilateral. Colonies are butryous, cream-coloured, smooth, semiglistening, umbonate and have an entire margin. Pseudohyphae are formed, but true hyphae are not formed in slide culture on cornmeal agar after 5 days at $25{ }^{\circ} \mathrm{C}$. Ascospores are not produced from individual strain or strains paired on $5 \%$ malt extract agar, Fowell's acetate agar, Gorodkowa agar or YM agar after 5 weeks at $25{ }^{\circ} \mathrm{C}$. The major ubiquinone is Q-9. Tests for fermentation of Dglucose, D-galactose (weak), maltose (weak), sucrose and $\alpha, \alpha$-trehalose are positive, but negative results are obtained for melibiose, lactose and raffinose. D-Glucose, D-galactose, L-sorbose, $N$-acetyl-D-glucosamine, D-xylose, sucrose, maltose, $\alpha, \alpha$-trehalose, methyl $\alpha$-D-glucoside, cellobiose (weak), salicin (weak), melezitose, glycerol, ribitol, Dglucitol, D-mannitol, D-glucono-1,5-lactone, 2-ketogluconic acid, D-gluconic acid, DL-lactic acid, succinic acid, citric 


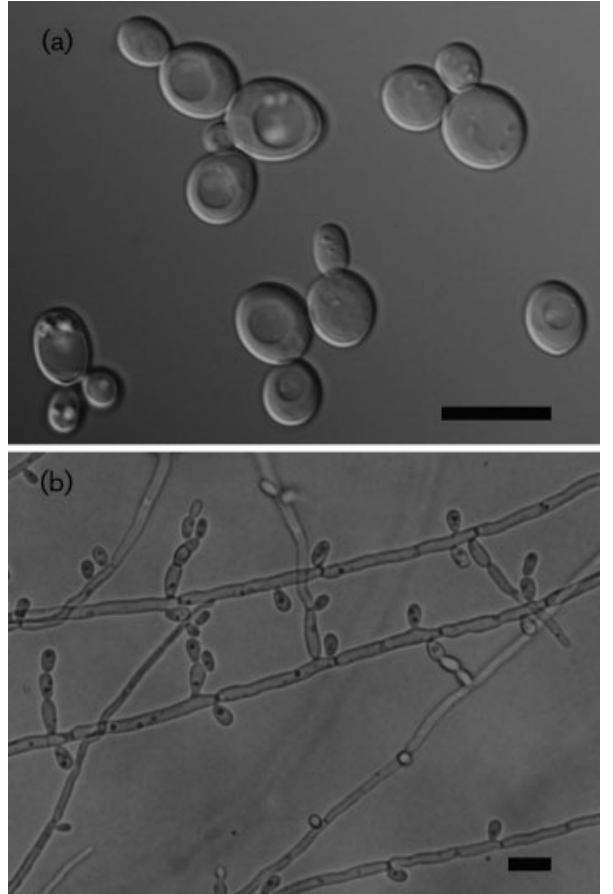

Fig. 2. Images of cells of Candida saraburiensis $\mathrm{sp}$. nov. $\mathrm{KU}-\mathrm{Xs} 13^{\top}$. (a) Cells grown on $\mathrm{YM}$ agar after 3 days at $25{ }^{\circ} \mathrm{C}$. (b) Pseudohyphae produced on cornmeal agar after 5 days at $25^{\circ} \mathrm{C}$. Bars, $10 \mu \mathrm{m}$.

acid, ethanol, ethylamine- $\mathrm{HCl}$, L-lysine- $\mathrm{HCl}$ and cadaverine are assimilated, but D-ribose, $\mathrm{L}$-arabinose, D-arabinose, L-rhamnose, melibiose, lactose, raffinose, inulin, soluble starch, erythritol, galactitol, inositol, 5-ketogluconic acid, D-glucuronic acid, D-galacturonic acid, methanol, potassium nitrate and sodium nitrite are not assimilated. Growth in vitamin-free medium is positive. Growth at $40{ }^{\circ} \mathrm{C}$ is positive, but no growth at $42{ }^{\circ} \mathrm{C}$. No growth with $0.01 \%$ or $0.1 \%$ cycloheximide. Growth is positive on media containing $50 \%(\mathrm{w} / \mathrm{v})$ glucose, $60 \%(\mathrm{w} / \mathrm{v})$ glucose, $10 \%(\mathrm{w} / \mathrm{v})$ sodium chloride/5\%(w/v) glucose or $16 \%$ $(\mathrm{w} / \mathrm{v})$ sodium chloride/5\% (w/v) glucose. Starch-like compounds are not produced. Diazonium blue B and urease reactions are negative.

The type strain $\mathrm{KU}-\mathrm{Xs13} 3^{\mathrm{T}} \quad\left(=\mathrm{CBS} \quad 11696^{\mathrm{T}}=\mathrm{NBRC}\right.$ $106721^{\mathrm{T}}=$ BCC $39601^{\mathrm{T}}$ ) was isolated from decaying corncobs collected in Saraburi province, Thailand.

\section{Latin diagnosis of Candida prachuapensis Boonmak, Nitiyon, Am-In, Jindamorakot, Kawasaki, Yongmanitchai et Limtong sp. nov.}

In agaro YM post dies 3 ad $25^{\circ} \mathrm{C}$ cellulae ovoidae aut cylindricae, $(3-6 \times 3-13 \mu \mathrm{m})$, singulae aut binae, per germinationem multipolarem reproducentes. Cultura butyrosa, cremea, centrum colonia altum et margine filamentum. In agaro farina Zea mays post dies 7 ad $25{ }^{\circ} \mathrm{C}$ pseudohyphae formantur, hyphae non formantur. Ascosporae non formantur. D-glucosum, sucrosum et maltosum fermentantur at non D-galactosum, lactosum, raffinosum nec $\alpha, \alpha$-trehalosum. DGlucosum, L-sorbosum, sucrosum, maltosum, cellobiosum, melibiosum (infirme), raffinosum, melezitosum, inulinum, amylum solubile, D-xylosum, ethanolum, glycerolum, ribitolum, D-mannitolum, D-glucitolum, methyl $\alpha$-D-glucosidium, salicinum, acidum DL-lacticum, acidum succinicum, acidum citricum, N-acetyl-D-glucosaminum, acidum 2-ketogluconicum, acidum 5-ketogluconicum, acidum D-gluconicum, Dglucono-1,5-lactonum, xylitolum, ethylaminum, L-lysinum et cadaverinum assimilantur. D-Galactosum, lactosum, L-arabinosum, D-arabinosum, D-ribosum, L-rhamnosum, erythritolum, galactitolum, inositolum, methanolum, acidum Dglucuronicum, acidum D-galacturonicum, kalium nitricum nec natrum nitrosum non assimilantur. Vitamina externa crescentiae non necessar sunt. Crescit in temperatura $42{ }^{\circ} \mathrm{C}$ (infirme) at non in $45{ }^{\circ} \mathrm{C}$. Non crescit in $0.01 \%$ cycloheximido nec $0.1 \%$ cycloheximido. Crescit in $50 \%$ glucosum, $60 \%$ glucosum et $10 \%$ natrii chloridum $/ 5 \%$ glucosum. Amylum non formatur. Ureum non hydrolysatur. Diazonium caeruluem B non respondens. Ubiquinonum majus: Q-8.

Typus stirpis $\mathrm{WB}^{\mathrm{T}}{ }^{\mathrm{T}}\left(=\mathrm{CBS} 11024^{\mathrm{T}}=\mathrm{NBRC} 104881^{\mathrm{T}}=\right.$ BCC $29904^{\mathrm{T}}$ ) isolatus aqua, Prachuap Khiri Khan provicia, Thailandica, conservatur in collectionibus culturarum quas Centraalbureau voor Schimmelcultures (Utrecht, The Netherlands), NITE Biological Resource Center (Chiba, Japan) et BIOTEC Culture Collection, National Centre for Genetic Engineering and Biotechnology, Thailand (Pathumthani, Thailand) deposita est.

\section{Description of Candida prachuapensis Boonmak, Nitiyon, Am-In, Jindamorakot, Kawasaki, Yongmanitchai \& Limtong sp. nov.}

Candida prachuapensis (pra.chuap.en'sis. N.L. fem. adj. prachuapensis of or belonging to Prachuap Khiri Khan, Thailand).

After growth on YM agar for 3 days at $25{ }^{\circ} \mathrm{C}$, cells are ovoid to cylindrical $(3-6 \times 3-13 \mu \mathrm{m})$ and occur singly, in pairs or in short chains (Fig. 3). Budding is multilateral. Colonies are butryous, cream-coloured and umbonate with a mycelial margin. Pseudohyphae are formed, but true hyphae are not formed in slide culture on cornmeal agar after 7 days at $25{ }^{\circ} \mathrm{C}$. Ascospores are not produced on $5 \%$ malt extract agar, Fowell's acetate agar, Gorodkowa agar or YM agar after 6 weeks at $15{ }^{\circ} \mathrm{C}$. The major ubiquinone is Q-8. Tests are positive for fermentation of D-glucose, sucrose and maltose, but negative results for D-galactose, lactose, raffinose and $\alpha, \alpha$-trehalose. D-Glucose, L-sorbose, sucrose, maltose, cellobiose, melibiose (weak), raffinose, melezitose, inulin, soluble starch, D-xylose, ethanol, glycerol, ribitol, D-mannitol, D-glucitol, methyl $\alpha$-D-glucoside, salicin, DL-lactic acid, succinic acid, citric acid, $\mathrm{N}$ acetyl-D-glucosamine, 2-ketogluconic acid, 5-ketogluconic acid, D-gluconic acid, D-glucono-1,5-lactone, xylitol, ethylamine- $\mathrm{HCl}, \mathrm{L}-\mathrm{lysine}-\mathrm{HCl}$ and cadaverine are assimilated, 

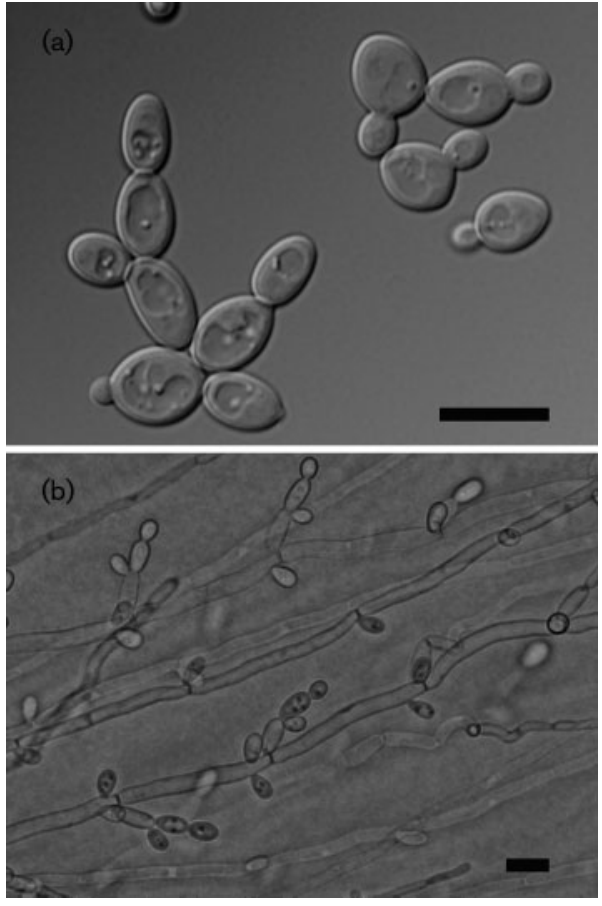

Fig. 3. Images of cells of Candida prachuapensis sp. nov. WB15 ${ }^{\top}$. (a) Cells grown on $\mathrm{YM}$ agar after 3 days at $25^{\circ} \mathrm{C}$. (b) Pseudohyphae produced on cornmeal agar after 5 days at $25{ }^{\circ} \mathrm{C}$. Bars, $10 \mu \mathrm{m}$.

but D-galactose, lactose, L-arabinose, D-arabinose, D-ribose, L-rhamnose, erythritol, galactitol, inositol, methanol, Dglucuronic acid, D-galacturonic acid, potassium nitrate and sodium nitrite are not assimilated. Growth in vitamin-free medium is positive. Weak growth at $42{ }^{\circ} \mathrm{C}$, but no growth at $45{ }^{\circ} \mathrm{C}$. Growth with $0.01 \%$ and $0.1 \%$ cycloheximide is negative. Growth on medium containing $50 \%(\mathrm{w} / \mathrm{v})$ glucose, $60 \%(\mathrm{w} / \mathrm{v})$ glucose or $10 \%(\mathrm{w} / \mathrm{v})$ sodium chloride $/ 5 \%(\mathrm{w} / \mathrm{v})$ glucose is positive. Starch-like compounds are not produced. Diazonium blue B and urease reactions are negative.

The type strain, $\mathrm{WB} 15^{\mathrm{T}}\left(=\mathrm{CBS} 11024^{\mathrm{T}}=\mathrm{NBRC} 104881^{\mathrm{T}}\right.$ $=$ BCC $29904^{\mathrm{T}}$ ), was isolated from water collected from a mangrove forest in Prachuap Khiri Khan province, Thailand.

\section{ACKNOWLEDGEMENTS}

This work was partially supported by the Thailand Graduate Institute of Science and Technology (TGIST) grant TGIST 01-51-023. Many thanks go to Ms Rungluk Kaewwichian and Mr Teera Yimyoo for their assistance.

\section{REFERENCES}

Altschul, S. F., Madden, T. L., Schäffer, A. A., Zhang, J., Zhang, Z., Miller, W. \& Lipman, D. J. (1997). Gapped BLAST and PSI-BLAST: a new generation of protein database search programs. Nucleic Acids Res 25, 3389-3402.

Barnett, J. A., Payne, R. W. \& Yarrow, D. (2000). Yeasts: Characteristics and Identification, 3rd edn. Cambridge: Cambridge University Press.

Cadete, R. M., Santos, R. O., Melo, M. A., Mouro, A., Goncaleves, D. L., Stambuk, B. U., Gomes, F. C. O., Lanchance, M. A. \& Rosa, C. A. (2009). Spathaspora arborariae sp. nov., a D-xylose-fermenting yeast species isolated from rotting wood in Brazil. FEMS Yeast Res 9, 13381342.

Carvalho, W., Silva, S. S., Vitolo, M., Felipe, M. G. A. \& Mancilha, I. M. (2002). Improvement in xylitol production from sugarcane bagasse hydrolysate achieved by the use of a repeated-batch immobilized cell system. Z Naturforsch C 57, 109-112.

Doran-Peterson, J., Cook, D. M. \& Brandon, S. K. (2008). Microbial conversion of sugars from plant biomass to lactic acid or ethanol. Plant J 54, 582-592.

Felsenstein, J. (1985). Confidence limits on phylogenies: an approach using the bootstrap. Evolution 39, 783-791.

Hahn-Hägerdal, B., Galbe, M., Gorwa-Grauslund, M. F., Lidén, G. \& Zacchi, G. (2006). Bio-ethanol: the fuel of tomorrow from the residues of today. Trends Biotechnol 24, 549-556.

Ji, Z. H., Jia, J. H. \& Bai, F. Y. (2009). Four novel Candida species in the Candida albicans/Lodderomyces elongisporus clade isolated from the gut of flower beetles. Antonie van Leeuwenhoek 95, 23-32.

Kimura, M. (1980). A simple method for estimating evolutionary rate of base substitutions through comparative studies of nucleotide sequences. J Mol Evol 16, 111-120.

Kuraishi, H., Katayama-Fujimura, Y., Sugiyama, J. \& Yokoyama, T. (1985). Ubiquinone systems in fungi. I. Distribution of ubiquinones in the major families of ascomycetes, basidiomycetes, and deuteromycetes, and their taxonomic implications. Trans Mycol Soc Jpn 26, 383-395.

Kurtzman, C. P. \& Fell, J. W. (1998). The Yeasts, A Taxonomic Study, 4th edn. Amsterdam: Elsevier.

Kurtzman, C. P. \& Robnett, C. J. (1997). Identification of clinically important ascomycetous yeasts based on nucleotide divergence in the $5^{\prime}$ end of the large-subunit (26S) ribosomal DNA gene. J Clin Microbiol 35, 1216-1223.

Kurtzman, C. P. \& Robnett, C. J. (1998). Identification and phylogeny of ascomycetous yeasts from analysis of nuclear large subunit (26S) ribosomal DNA partial sequences. Antonie van Leeuwenhoek 73, 331371.

Kurtzman, C. P., Robnett, C. J. \& Yarrow, D. (2001). Two new anamorphic yeasts: Candida germanica and Candida neerlandica. Antonie van Leeuwenhoek 80, 77-83.

Lachance, M. A., Bowles, J. M., Starmer, W. T. \& Baker, S. F. (1999). Kodamaea kadaduensis and Candida tolerans, two new ascomycetous yeast species from Australian Hibiscus flowers. Can J Microbiol 45, 172-177.

Limtong, S., Yongmanitchai, W., Kawasaki, H. \& Seki, T. (2007a). Candida thaimueangensis sp. nov., an anamorphic yeast species from estuarine water in a mangrove forest in Thailand. Int J Syst Evol Microbiol 57, 650-653.

Limtong, S., Yongmanitchai, W., Tun, M. M., Kawasaki, H. \& Seki, T. (2007b). Kazachstania siamensis sp. nov., an ascomycetous yeast species from forest soil in Thailand. Int J Syst Evol Microbiol 57, 419422.

Meyer, S. A., Payne, R. W. \& Yarrow, D. (1998). Candida Berkhout. In The Yeasts, A Taxonomic Study, 4th edn, pp. 454-573. Edited by C. P. Kurtzman \& J. W. Fell. Amsterdam: Elsevier. 
Nakase, T. \& Suzuki, M. (1986). Bullera megalospora, a new species of yeast forming larger ballistospores isolated from dead leaves of Oryza sativa, Miscanthus sinesis and Sasa sp. in Japan. J Gen Appl Microbiol 32, 225-240.

Nguyen, N. H., Suh, S. O., Marshall, C. J. \& Blackwell, M. (2006). Morphological and ecological similarities: wood-boring beetles associated with novel xylose-fermenting yeasts, Spathaspora passalidarum gen. sp. nov. and Candida jeffriesii sp. nov. Mycol Res 110, 1232-1241.

Nguyen, N. H., Suh, S. O. \& Blackwell, M. (2007). Five novel Candida species in insect-associated yeast clades isolated from Neuroptera and other insects. Mycologia 99, 842-858.

O'Donnell, K. (1993). Fusarium and its near relatives. In The Fungal Holomorph: Mitotic and Pleomorphic Speciation in Fungal Systematics, pp. 225-233. Edited by D. R. Reynolds \& J. W. Taylor. Wallingford, UK: CAB International.

Rao, R. S., Bhadra, B., Kumar, N. N. \& Shivaji, S. (2007). Candida hyderabadensis sp. nov., a novel ascomycetous yeast isolated from wine grapes. FEMS Yeast Res 7, 489-493.

Saitou, N. \& Nei, M. (1987). The neighbor-joining method: a new method for reconstructing phylogenetic trees. Mol Biol Evol 4, 406-425.
Suh, S. O., Nguyen, N. H. \& Blackwell, M. (2008). Yeasts isolated from plant-associated beetles and other insects: seven novel Candida species near Candida albicans. FEMS Yeast Res 8, 88-102.

Thompson, J. D., Gibson, T. J., Plewniak, F., Jeanmougin, F. \& Higgins, D. G. (1997). The CLUSTAL_X windows interface: flexible strategies for multiple sequence alignment aided by quality analysis tools. Nucleic Acids Res 25, 4876-4882.

Toivola, A., Yarrow, D., van den Bosch, E., van Dijken, J. P. \& Scheffers, W. A. (1984). Alcoholic fermentation of D-xylose by yeasts. Appl Environ Microbiol 47, 1221-1223.

Vallini, G., Frassinetti, S. \& Scorzetti, G. (1997). Candida aquaetextoris sp. nov., a new species of yeast occurring in sludge from a textile industry wastewater treatment plant in Tuscany, Italy. Int J Syst Bacteriol 47, 336-340.

Yamada, Y. \& Kondo, K. (1973). Coenzyme Q system in the classification of the yeast genera Rhodotorula and Cryptococcus, and the yeast-like genera Sporobolomyces and Rhodosporidium. J Gen Appl Microbiol 19, 59-77.

Yarrow, D. (1998). Methods for the isolation, maintenance and identification of yeasts. In The Yeasts, a Taxonomic Study, 4th edn, pp. 77-100. Edited by C. P. Kurtzman \& J. W. Fell. Amsterdam: Elsevier. 